\title{
SIMULASI PEMILIHAN TURBIN AIR MENGGUNAKAN SIMULATOR TURBNPRO STUDI KASUS PLTMH MALABAR
}

\author{
Rony Darpono', Riyani Prima Dewi ${ }^{2}$ \\ ${ }^{12}$ Teknik Elektronika Politeknik Harapan Bersama Tegal (9 pt) \\ email: ${ }^{1}$ ronydr80@gmail.com, ${ }^{2}$ riyanipdewi@gmail.com
}

\begin{abstract}
Indonesia mempunyai potensi tenaga air yang sangat besar dikembangkan baik dalam PLTA skala besar maupun mini dan mikro. Tetapi untuk mengembangkan hydro power dibutuhkan kajian-kajian yang rumit dan biaya yang tinggi, ditambah dengan kondisi alam Indonesia yang menyulitkan dalam survey lokasi menjadi hambatan dikembangkannya hydro power skala kecil. Dalam tugas akhir ini dipaparkan suatu metode pendekatan dalam analisis potensi dikembangkan hydro power. Metode ini memungkinkan seseorang dapat menganalisis potensi suatu sumber air dengan data lapangan yang telah ada. Dalam metode ini diambil contoh kasus aliran sungai di Perkebuna Malabar dalam kajian potensi enegri listrik yang dapat dihasilkan di daerah tersebut. Karena geografis perkebunan Malabar berupa bukit, maka pengambilan satu titik lokasi untuk dijadikan pembangkit harus mempertimbangkan arah gerakan tanah agar aman dari kemungkinan longsor.

Kata Kunci : Pembangkit Listrik Tenaga Air, Head Efektif, Debit Andalan.
\end{abstract}

\section{PENDAHULUAN}

Seiring dengan meningkatnya pembangunan terutama pembangunan di sektor industri, pertumbuhan ekonomi dan pertumbuhan penduduk, kebutuhan akan energi khususnya energi listrik terus meningkat. Penyediaan energi di masa depan merupakan permasalahan yang senantiasa menjadi perhatian semua bangsa karena bagaimanapun juga kesejahteraan manusia dalam kehidupan modern sangat terkait dengan jumlah dan mutu energi yang dimanfaatkan. Bagi Indonesia yang merupakan salah satu negara sedang berkembang, penyediaan energi merupakan faktor yang sangat penting dalam mendorong pembangunan.

Adanya isu tentang pemanasan global, konversi bahan bakar minyak menjadi batubara dan gas bumi akan menjadi tidak popular di masa depan, karena batubara menghasilkan emisi karbon yang sangat besar. Jadi dibutuhkan alternatif energi lain sebagai pengganti bahan bakar fosil (minyak bumi, batubara, dan gas alam). Energi alternatif tersebut dapat berupa energi yang dapat dapat diperbarui seperti: angin, matahari, air, dan biomass yang belum secara optimal dimanfaatkan di Indonesia.

\section{TINJAUAN PUSTAKA \\ 2.1 Tinjau Pustaka}

Pada tinjauan pustaka ini membahas penelitian sebelumnya terkait tentang Pembangkit Listrik Tenaga Mikro Hidro (PLTMH) sebagai berikut:

1. Suwignyo, Perencaan dan pembuatan Turbin Propeller untuk Pembangkit Listrik Tenaga Mikro Hidro (PLTMH), Seminar Nasional Sains dan Teknologi Terapan V, 2017. Penelitian ini membahas kegiatan awal (pengembangan syarat dan data teknis) dilakukan dengan pengukuran data primer (debit air dan tinggi jatuh hidrolik) untuk menentukan daerah kerja dan tipe turbin yang bersesuaian. Dilanjutkan dengan perencanaan kecepatan spesifik (Dimensionless specific speed) secara grafis dan atau analitis. Analisa desain turbin diawali dengan pemilihan tipe turbin, dilanjutkan perhitungan daya hidrolik dan perencanaan kecepatan spesifik. Analisa desain komponen turbin hidro meliputi analisa desain hidrolik sudu turbin, sudu pengarah aliran, poros turbin dan lainnya. Penggambaran desain komponen turbin hidro secara keseluruhan didasarkan pada dimensi hasil analisa hidrolik dan analisa mekanik dari masing-masing komponen turbin. Gambar desain rinci dijadikan dasar pembuatan/ pabrikasi komponen turbin dan dijadikan dokumen bahan evaluasi desain dan kegiatan pengujian kinerja turbin.

2. Ade Rahmat, Simulasi perancangan Turbin Propeller sumbu Vertikal untuk pembangkit listrik Tenaga Mikrohidro, Univertitas andalas 2011. Pada penelitian ini membahas tentang karakteristik turbin propeler head rendah berdasarkan hasil simulasi perhitungan, dan perancangan serta membandingkan hasil simulasi perhitungan dan perancangan dengan referensi dan Mengetahui pengaruh dari perbedaan input yang diberikan terhadap dimensi komponen pendukung pada perancangan turbin propeller.

3. Danny Samuel Pelupessy, Pemilihan Type Turbin pada Pembangkit Listrik Tenaga Mikro Hidro (PLTMH), Jurnal Teknologi Volume 9, 2012. Penelitian ini membahas tentang Potensi air sungai Cimuja dapat menghasilkan tenaga listik $52 \mathrm{~kW}$, dan turbin yang cocok digunakan adalah type Crossflow. Ditinjau dari berbagai sudut pandang, proyek PLTMH ini termasuk ramah lingkungan. Pemanfaatan air sungai tidak akan menggangu habitat flora dan fauna sepanjang sungai, karena air hanya dipinjam dan diambil energinya saja, sedangkan airnya dikembalikan ke aliran sungai. Proyek pembangunan PLTMH ini akan membawa manfaat yang besar bagi kelangsungan hidup masyarakat desa serta flora dan fauna disekitarnya. 


\subsection{Hidrologi}

Siklus hidrologi adalah sirkulasi air yang tidak pernah berhenti dari atmosfer ke bumi dan kembali ke atmosfer melalui kondensasi, presipitasi, evaporasi dan transpirasi. Matahari sebagai sumber energi terbesar di alam semesta memberikan pengaruh paling besar dalam proses siklus hidrologi. Siklus hidrologi berawal dari penguapan air laut, sungai, danau dan sebagainya, namun yang terbesar adalah air laut. Penguapan air laut memungkinkan terjadinya siklus hidrologi yang berlangsung terus menerus. Air berevaporasi, selanjutnya jatuh ke bumi sebagai presipitasi dalam berbagai bentuk seperti hujan, hujan es, salju, gerimis, bahkan kabut sekalipun.

Pada perjalanan menuju ke bumi, beberapa presipitasi dapat berevaporasi kembali ke atas atau langsung jatuh yang kemudian diintersepsi oleh tanaman sebelum mencapai tanah. Setelah mencapai tanah, siklus hidrologi terus bergerak secara berkelanjutan dalam 3 cara yang berbeda, yaitu:

$>$ Evaporasi atau transpirasi, adalah suatu keadaan dimana terjadi penguapan oleh air yang terdapat di laut, sungai, danau, tanamanan, dan di darat menuju ke atmosfer bumi. Partikel-partikel uap air hasil dari penguapan tadi akan membentuk awan. Pada keadaan tertentu, dimana terjadi peningkatan massa jenis pada kumpulan partikel uap air tersebut, maka uap air akan turun ke bumi (precipitation) dalam bentuk hujan, salju, mapun es.

$>$ Infiltrasi atau Perkolasi, adalah suatu keadaan dimana terjadi pergerakan air didalam tanah lewat saluransaluran yang ada pada celah dan pori-pori tanah serta batuan menuju muka air tanah. Air dapat bergerak akibat aksi kapiler atau air dapat bergerak secara vertikal atau horizontal di bawah permukaan tanah hingga air tersebut memasuki kembali sistem air permukaan.

Air Permukaan, yaitu suatu keadaan dimana air bergerak di atas permukaan tanah dekat dengan aliran utama dan danau. Pergerakan air ini dipengaruhi oleh landai atau tidaknya bentuk permukaan tanah dan saluran celah dan pori-pori pada tanah. Semakin landai bentuk tanah dan semakin sedikit pori-pori tanah, maka aliran permukaan semakin besar. Aliran permukaan tanah dapat dilihat biasanya pada daerah urban. Sungai-sungai bergabung satu sama lain dan membentuk sungai utama yang membawa seluruh air permukaan di sekitar daerah aliran sungai menuju laut.

Air permukaan, baik yang mengalir maupun yang tergenang (danau, waduk, rawa), dan sebagian air bawah permukaan akan terkumpul dan mengalir membentuk sungai dan berakhir ke laut. Proses perjalanan air di daratan itu terjadi dalam komponen-komponen siklus hidrologi yang membentuk sistem Daerah Aliran Sungai (DAS).

Sungai adalah aliran air yang besar dan memanjang yang mengalir secara terus-menerus dari hulu (sumber) menuju hilir (muara). Kemanfaatan terbesar sebuah sungai adalah untuk irigasi pertanian, bahan baku air minum, sebagai saluran pembuangan air hujan dan air limbah, bahkan potensial untuk dimanfaatkan sebagai pembangkit listrik tenaga air.
Konsep kerja pembangkit listrik tenaga air itu sendiri cukup sederhana, yaitu mengubah energi potensial air pada ketinggian menjadi energi putar mekanis dengan menggunakan turbin air dan kemudian energi mekanis tersebut diubah menjadi energi listrik menggunakan generator.

Pada gambar 2.1 dapat dilihat skema dari pembangkit listrik tenaga air. Air pada sungai mengalir menuruni suatu ketinggian, di salah satu titik ketinggian air dibendung untuk dialirkan pada saluran (pipa/penstock). Energi potensial air pada ketinggian tersebut kemudian dialirkan menuju turbin melalui penstock sehigga turbin berputar. Putaran turbin itu akan menggerakkan rotor generator yang akan menghasilkan listrik. Listrik yang dihasilkan tersebut kemudian disesuaikan tegangannya dengan tegangan jaringan menggunakan transformator untuk disalurkan kepada konsumen.

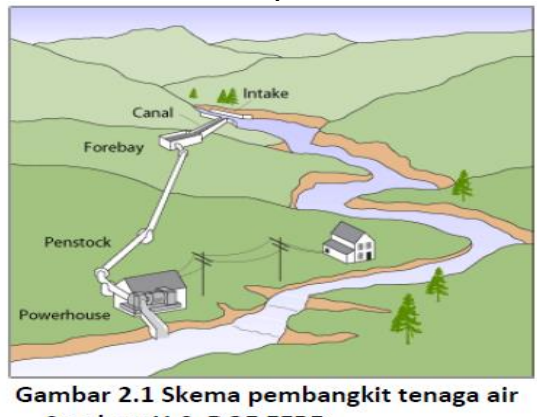

Sumber: U.S. DOE EERE

Dari skema pembangkitan listrik tenaga air, dapat diambil besaran-besaran utama yang penting dalam analisis pembangunan PLTA tersebut. Besaran-besaran utama tersebut antara lain : head, debit air, potensi daya, dan efisiensi.

Head adalah perbedaan ketinggian dua titik pada kolom cairan dan menghasilkan tekanan pada titik yang lebih rendah. Atau dikenal dengan perbedaan ketinggian permukaan air bagian atas dengan bagian bawah tempat turbin diletakkan[7]. Debit adalah kapasitas aliran (Q) yang merupakan sejumlah kubik (volume) cairan yang dipindahkan dalam waktu tertentu, biasanya diberikan satuan $\mathrm{m} 3 / \mathrm{s}$. Umumnya suatu sumber air, kapasitas alirannya berubahubah tergantung dari besar kecilnya curah hujan dan beberapa faktor lainnya.

Sedangkan daya yang dapat dikonversikan adalah energi per satuan waktu, dalam hal ini per detik, dan volume per detik adalah debit, sehingga persamaan daya menjadi:

Dengan :

$$
P=(\rho . Q . g . H) k W
$$

$\mathrm{P}=$ Potensi daya listrik $(\mathrm{kW})$

$\rho=$ massa jenis air $[\mathrm{kg} / \mathrm{m} 3]$

$\mathrm{H}=$ head ( ketinggian jatuh air ) [meter]

$\mathrm{Q}=$ debit air $[\mathrm{m} 3 / \mathrm{s}]$

$\mathrm{g}=$ percepatan gravitasi bumi $[\mathrm{m} / \mathrm{s} 2]$

$\eta=$ efisiensi total efisiensi sistem ( turbin, generator, dan pekerjaan sipil )

\section{METODE PENELITIAN 3.1 Tahapan Penelitian}

Penelitian ini terdiri dari beberapa tahapan. Tahapantahapan pelaksanan penelitian ini adalah sebagai berikut : 
1. Tinjauan Pustaka, dilakukan dengan mempelajari buku referensi, makalah, artikel, maupun sumbersumber lainnya yang berhubungan dengan pembangkit listrik tenaga air.

2. Pengambilan sample data lokasi dari pihak-pihak yang berwenang.

3. Melakukan pendekatan pengukuran lapangan dengan software untuk mendapatkan data yang belum tercatat seperti:

- Mengidentifikasi kemungkinan site untuk dibangun menjadi area pembangkit

- Mengukur head yang tersedia dari site

- Mengidentifikasi lokasi kemungkinan penempatan power house

4. Melakukan analisis debit andalan menggunakan metode F.J Mock.

5. Melakukan site visit untuk mengkonfimasi data hasil pengamatan dengan software.

6. Penghitungan potensi daya listrik yang dapat dihasilkan.

7. Kesimpulan dan penulisan laporan penelitian.

Berikut adalah flowchart dalam melakukan penelitian ini :

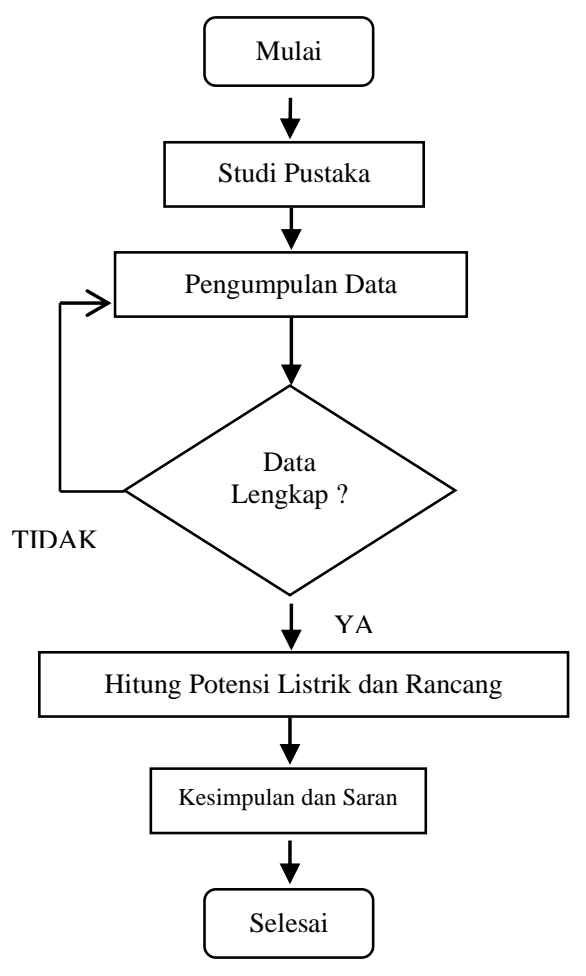

Gambar 3.1 Flowchart Penelitian

\subsection{Data dan Software}

Data yang perlu dikumpulkan untuk melakukan penelitian ini diantaranya :

1. Data Debit harian Suangi Cilaki

2. Peta topografi wilayah perkebunan Malabar

3. Data klimatologi wilayah perkebunan Malabar

Jurnal homepage: http://ejournal.poltektegal.ac.id/index.php/powerel
Sedangkan software yang dipakai untuk membantu proses menghitung dan analisis adalah Ms.Excle dan Google Earth.

\section{HASIL DAN PEMBAHASAN}

\subsection{Analisis Hidrologi}

\subsubsection{Metode Perhitungan Debit}

\section{A. Metode F.J Mock}

Analisis debit empiris dengan menggunakan data curah hujan dan kimatologi menggunakan metode F.J Mock, yaitu analisis keseimbangan air untuk menghitung harga debit bulanan berdasarkan tranformasi data curah hujan bulanan, evapotranspirasi, kelembapan tanah dan tampungan air tanah.

Prinsip metode F.J Mock menyatakan bahwa hujan yang jatuh pada daerah tangkapan air, sebagian akan hilang akibat evapotranspirasi, sebagian akan langsung menjadi direct Runoff dan sebagian lagi akan masuk ke dalam tanah atau terjadi infiltrasi. Infiltrasi ini mula-mula akan menjenuhkan permukaan tanah, kemudian terjadi perkolasi ke air tanah dan akan keluar sebagai base flow. Hal ini terdapat keseimbangan antara air hujan yang jatuh dengan evapotranspirasi, direct runoff dan infiltrasi, dimana infiltrasi ini kemudian berupa soil moisture dan ground water discharge. Aliran dalam sungai adalah jumlah aliran yang langsung di permukaan tanah dan base flow.

Adapun langkah-langkah perhitungan Metode F.J Mock dijabarkan sebagai berikut.

1. Data meteorologi

Data meterologi yang digunakan mencakup :

a. Data presipitasi dalam hal ini adalah curah hujan bulanan dan data curah hujan harian.

b. Data klimatologi berupa data kecepatan angin, kelembapan udara, tempratur udara dan penyinaran matahari untuk menentukan Evapotranspirasi potensial (Eto) yang dihitung berdasarkan metode "Penman Modifikasi“.

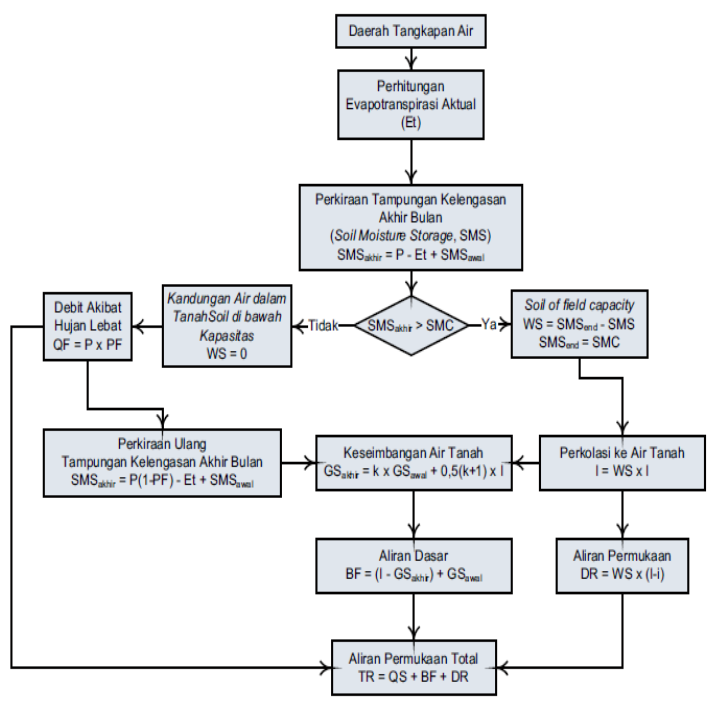


Gambar 4.1 flow chart Perhitungan Metode F.J Mock Sumber : Sinaro dkk, 1987

2. Evapotranspirasi Aktual ( Ea)

Penentuan harga evapotranspirasi aktual ditentuakan berdasarkan persamaan:

$$
E=E T o x \frac{d}{30} x m \quad E=
$$

ETo $x(m / 20) x(18-n)$

$E=E T o-E$

Dengan :

$\mathrm{Ea}=$ Evapotranspirasi aktual $(\mathrm{mm})$

Eto $=$ Evapotranspirasi potensial $(\mathrm{mm})$

$\mathrm{d}=27-(3 / 2) \times \mathrm{n}$

$\mathrm{n}=$ jumlah hari hujan dalam sebulan

$\mathrm{m}=$ Perbandingan permukaan tanah tanah yang tidak tertutup dengan tumbuh-tumbuhan penahan hujan koefisien yang tergantung jenis areal dan musiman dalam \% )

$\mathrm{m}=0$ untuk lahan dengan hutan lebat.

$\mathrm{m}=$ Untuk lahan dengan hutan sekunder pada akhir musim dan bertambah $10 \%$ setiap bulan berikutnya.

$\mathrm{m}=10-40 \%$ untuk lahan yang erosi

$\mathrm{m}=30-50 \%$ untuk lahan pertanian yang diolah ( sawah )

3. Keseimbangan air dipermukaan tanah $(\Delta S)$

a. Air hujan yang mencapai permukaan tanah dapat dirumuskan sebagai berikut :

\section{$\Delta \mathrm{S}=\mathrm{R}-\mathrm{Ea}$}

\section{Dengan :}

$\Delta \mathrm{S}=$ Keseimbangan air dipermukaan tanah

$\mathrm{R}=$ Hujan Bulanan

$\mathrm{Ea}=$ Evapotranspirasi Aktual

Bila harga positif $(\mathrm{R}>\mathrm{Ea})$ maka air akan masuk ke dalam tanah bila kapasitas kelembapan tanah belum terpenuhi. Sebaliknya bila kondisi kelembapan tanah sudah tercapai maka akan terjadi limpasan permukaan (surface runoff).

Bila harga tanah $\Delta S$ negatif ( $\mathrm{R}>\mathrm{Ea}$ ), air hujan tidak dapat masuk kedalam tanah (infltrasi) tetapi air tanah akan keluar dan tanah akan kekurangan air (defisit).

b. Perubahan kandungan air tanah (soil storage) tergantung dari harga $\Delta \mathrm{S}$. Bila $\Delta \mathrm{S}$ negatif maka kapasitas kelembapan tanah akan kekurangan dan bila harga $\Delta \mathrm{S}$ positif akan menambah kekurangan kapasitas kelembapan tanah bulan sebelumnya.

c. Kapasitas kelembapan tanah (soil moisture capacity).

Di dalam memperkirakan kapasitas kelembapan tanah awal diperlukan pada saat dimulainya perhitungan dan besarnya tergantung dari kondisi porositas lapisan tanah atas dari daerah pengaliran. Biasanya diambil $50 \mathrm{~s} / \mathrm{d} 250 \mathrm{~mm}$, yaitu kapasitas kandungan air didalam tanah per $\mathrm{m}^{3}$, semakin besar porositas tanah maka kelembapan tanah akan besar pula.

d. Kelebihan Air (water surplus)

Besarnya air lebih dapat mengikuti formula sbb : $W S=\Delta S-$ Tampungan Tanah

Dengan :

$\mathrm{WS}=$ water surplus

$\Delta \mathrm{S}=\mathrm{R}-\mathrm{Ea}$

Tampungan Tanah $=$ Perbedaan

Kelembapan tanah

4. Limpasan dan penyimpanan air tanah (Run off dan Ground Water storage )

a. Infiltrasi (i)

Infiltrasi ditaksir berdasarkan kondisi porositas tanah dan kemiringan daerah pengaliran. Daya infiltrasi ditentukan oleh permukaan lapisan atas dari tanah. Misalnya kerikil mempuyai daya infiltrasi yang lebih tinggi dibandingkan dengan tanah liat yang kedap air. Untuk lahan yang terjal dimana air sangat cepat menikis diatas permukaan tanah sehingga air tidak dapat sempat ber-infltrasi yang menyebabkan daya infiltrasi lebih kecil. Formula dari infiltrasi ini adalah sebagai berikut :

$$
\begin{aligned}
& i=\text { Koefisien infiltrasi } x W S \\
& \text { Dengan : } \\
& \mathrm{i}=\text { Infiltrasi (Koefisien Infiltrasi (i) }=0 \mathrm{~s} / \mathrm{d} \\
& \text { WS = kelebihan air }
\end{aligned}
$$$$
1,0)
$$

b. Penyimpanan air tanah (ground water storage)

Pada permulaan perhitungan yang telah ditentukan penyimpanan air awal yang besarnya tergantung dari kondisi geologi setempat dan waktu. Persamaan yang digunakan adalah (sumber : PT. Tricon Jaya, Sistim Planing Irigasi Ongka Persatuan Kab. Donggala Hal V-4)

$\mathrm{V}_{\mathrm{n}}=\mathrm{k}\left(\mathrm{V}_{\mathrm{n}-1}\right)+1 / 2(1+k) i_{\mathrm{n}}$

Dengan :

$\mathrm{V}_{\mathrm{n}}=$ Volume simpanan ait tanah periode $\mathrm{n}\left(\mathrm{m}^{3}\right)$ $\mathrm{V}_{\mathrm{n}-1}=$ Volume simpanan air tanah periode $\mathrm{n}-1$ $\left(\mathrm{m}^{3}\right)$

$k=\mathrm{q} / \mathrm{q}_{\mathrm{o}}$ merupakan faktor resesi aliran air tanah (catchment are recession factor) Faktor resesi aliran tanah $(\mathrm{k})$ berkisar antara $0 \mathrm{~s} / \mathrm{d} 1$

$\mathrm{q}_{\mathrm{t}}=$ Aliran tanah pada waktu $\mathrm{t}$ (bulan ke $\mathrm{t}$ )

$\mathrm{q}_{\mathrm{o}}=$ Aliran tanah pada awal (bulan ke 0)

$\mathrm{i}_{\mathrm{n}}=$ Infiltrasi bulan ke $\mathrm{n}(\mathrm{mm})$

Untuk mendapatkan perubahan volume aliran air dalam tanah mengikuti persamaan :

$\Delta \mathrm{V}_{\mathrm{n}}=\mathrm{V}_{\mathrm{n}}-\mathrm{V}_{\mathrm{n}-1}$

c. Limpasan (Run off)

Air hujan atau presipitasi akan menempuh tiga jalur menuju ke sungai. Satu bagian akan 
mengalir sebagai limpasan permukaan dan masuk kedalam tanah lalu mengalir ke kiri dan kananya membentuk aliran antara. Bagian ketiga akan berperkolasi jauh kedalam tanah hingga mencapai lapisan air tanah. Aliran permukaan tanah serta aliran antara sering digabungkan sebagai limpasan langsung (direct runoff). Untuk memperoleh limpasan, maka persamaan yang digunakan adalah :

$\mathrm{BF}=\mathrm{I}-(\Delta \mathrm{Vn})$

$\mathrm{D}_{\text {ro }}=\mathrm{WS}-\mathrm{I}$

$\mathrm{R}_{\mathrm{on}}=\mathrm{BF}+\mathrm{D}_{\mathrm{ro}}$

Dengan :

$\mathrm{BF}=$ Aliran dasar $\left(\mathrm{M}^{3} / \mathrm{dtk} / \mathrm{km}\right)$

$\mathrm{I}=$ Infltrasi $(\mathrm{mm})$

(M3)

$\Delta \mathrm{Vn}=$ Perubahan volume aliran tanah

$\mathrm{D}_{\mathrm{ro}}=$ Limpasan Langsung $(\mathrm{mm})$

$\mathrm{WS}=$ Kelebihan air

$\mathrm{R}_{\mathrm{on}}=$ Limpasan periode $\mathrm{n}\left(\mathrm{M}^{3} / \mathrm{dtk} / \mathrm{km}^{2}\right)$

d. Banyaknya air yang tersedia dari sumbernya.

Persamaan yang digunakan adalah

$\mathrm{Q}_{\mathrm{n}}=\mathrm{R}_{\mathrm{on}} \times \mathrm{A}$

Dengan :

$\mathrm{Q}_{\mathrm{n}}=$ Banyaknya air yg tersedia dari sumbernya periode $n\left(\mathrm{~m}^{3} / \mathrm{bln}\right)$

$\mathrm{A}=$ Luas daerah tangkapan (catchment area) $\mathrm{Km}^{2}$

\subsubsection{Perhitungan Debit Andalan}

A. Perhitungan Evapotranspirasi Potensial (ETo) Untuk menghitung evapotranspirasi potensial (ETo) digunakan metode "Penman Modifikasi" dengan persamaan 4.13 . Contoh perhitungan ETo untuk bulan Januari :

Diketahui :

Data rerata Klimatologi seperti pada Tabel adalah sebagai berikut,

1. Temperatur rata-rata, $\mathrm{T}=24,22^{\circ} \mathrm{C}$

2. Kelembaban udara relatif, $\mathrm{RH}=79,27 \%$

3. Kecepatan angin, $\mathrm{u}=2,1085 \mathrm{~m} / \mathrm{det}$

4. Penyinaran matahari, $\mathrm{n} / \mathrm{N}=44,20 \%$

\section{Langkah 1 :}

Dengan data $\mathrm{T}=24,22^{\circ} \mathrm{C}$ dan data Tabel 1 pada Lampiran

D, didapat :

Tekanan uap jenuh (Ea), melalui interpolasi didapat :

$\mathrm{T}=24,2^{\circ} \mathrm{C} \rightarrow$ ea $=30.213$

$\mathrm{T}=24.4^{\circ} \mathrm{C} \rightarrow$ ea $=30.581$

Maka dengan interpolasi :

$$
\mathrm{T}=24,22^{\circ} \mathrm{C} \rightarrow \text { ea }=30.213+\frac{30.581-30.213}{24.4-24,2} \times(24,22-
$$

$$
\text { ea }=30,2498 \text { m.bar }
$$

Faktor penimbang suhu dan elevasi daerah (W)

$$
\mathrm{T}=24,2^{\circ} \mathrm{C} \rightarrow \mathrm{W}=0.737
$$$$
\mathrm{T}=24.4{ }^{\circ} \mathrm{C} \rightarrow \mathrm{W}=0.73
$$

Maka dengan interpolasi :

$\mathrm{T}=24,22^{\circ} \mathrm{C} \rightarrow \mathrm{W}=0,7372$

Fungsi suhu, $\mathrm{f}(\mathrm{T})$

$\mathrm{T}=24,2^{\circ} \mathrm{C} \rightarrow \mathrm{f}(\mathrm{T})=15.445$

$\mathrm{T}=24.4{ }^{\circ} \mathrm{C} \rightarrow \mathrm{f}(\mathrm{T})=15.491$

Maka dengan interpolasi :

$\mathrm{T}=24,22^{\circ} \mathrm{C} \rightarrow \mathrm{f}(\mathrm{T})=15,4496$ m.bar

\section{Langkah 2 :}

Dengan data : $\mathrm{RH}=79,27 \%$

Tekanan uap aktual (ed) diperoleh dari persamaan 4.18 :

$$
\text { ed }=\text { ea } \times \text { RH }
$$

$$
=30,2498 \times 79,27 \%
$$

$=23,9803 \mathrm{~m}$. bar

Perbedaan tekanan uap jenuh dengan tekanan uap sebenarnya :

ea - ed $=30,2498-23,9803=6,2695$ m.bar

Fungsi tekanan uap, $\mathrm{f}(\mathrm{ed})$

$$
\begin{aligned}
\mathrm{f}(\mathrm{ed}) & =044-034 \sqrt{e d} \\
& =0,14412
\end{aligned}
$$

\section{Langkah 3 :}

Dengan data :

- Koordinat 7012'00" - 7014'00” Lintang Selatan

- Rasio keawanan, $\mathrm{n} / \mathrm{N}=$ Penyinaran matahari $=44,20 \%$

- Tabel 2 pada Lampiran D

Didapat besaran :

Radiasi ekstra matahari, Ra didapat melalui interpolasi:

Januari, 6 LS $=15.80$

$$
8 \mathrm{LS}=16.10
$$

Jadi 7 LS = 15,95 $\mathrm{mm} / \mathrm{hari}$

Radiasi yang diterima matahari, Rs diperoleh dari persamaan 4.14 :

Rs $=(0,25+0,54 \times 44,20 \%) \times 15,95$

$\mathrm{Rs}=7,79481 \mathrm{~mm} / \mathrm{hari}$

Fungsi Rasio keawanan $\mathrm{f}(\mathrm{n} / \mathrm{N})$ didapat melalui persamaan 4.17:

$\mathrm{f}(\mathrm{n} / \mathrm{N})=0,1+0,9 \times 44,20 \%$

$\mathrm{f}(\mathrm{n} / \mathrm{N})=0,49784$

\section{Langkah 4 :}

Dengan data : Kecepatan angin, $\mathrm{u}=2,1085 \mathrm{~m} / \mathrm{det}$

Didapat besaran :

Fungsi kecepatan angin $\mathrm{f}(\mathrm{u})$ didapat melalui persamaan (4.16):

$$
\begin{aligned}
& f(u)=0.27(1+u \cdot 0.864) \\
& =0.27(1+2,1085 \times 0.864) \\
& =0,76187
\end{aligned}
$$

\section{Langkah 5 :}

Menghitung besaran radiasi bersih gelombang panjang (Rn1) mm/hari dengan persamaan (4.15) :

$$
\begin{aligned}
& \mathrm{Rn} 1=\mathrm{f}(\mathrm{t}) \times \mathrm{f}(\mathrm{ed}) \times \mathrm{f}(\mathrm{n} / \mathrm{N}) \\
& \mathrm{Rn} 1=15,4496 \times 0,14412 \times 0,49784 \\
& \mathrm{Rn} 1=1,10849 \mathrm{~mm} / \mathrm{hari}
\end{aligned}
$$

\section{Langkah 6 :}


Menghitung faktor koreksi c berdasarkan perkiraan perbandingan kecepatan angin siang/malam di Indonesia. Dengan faktor koreksi $\mathrm{c}=1,1$

Rns $=(1-\mathrm{a}) \mathrm{Rs}$

dengan nilai $\mathrm{a}=0,25$ dan $\mathrm{Rs}=7,79481 \mathrm{~mm} / \mathrm{hari}$

Rns $=(1-0,25) \times 7,79481$

$\mathrm{Rns}=5,84611 \mathrm{~mm} / \mathrm{hari}$

Jadi, $\mathrm{Rn}=\mathrm{Rns}-\mathrm{Rn} 1$

$\mathrm{Rn}=5,84611-1,10849$

$\mathrm{Rn}=4,73761 \mathrm{~mm} / \mathrm{hari}$

\section{Langkah 7 :}

Menghitung ETo dengan persamaan :

$\mathrm{ETo}=\mathrm{C}[\mathrm{W} . \mathrm{Rn}+(1-\mathrm{W}) \times(\mathrm{f}(\mathrm{u}) \times(\mathrm{ea}-\mathrm{ed})]$

$=1.1[0,7372(4,73761)+(0,2628)(0,76187)(6,2695)$

$=5,22263 \mathrm{~mm} / \mathrm{hari}$

ETo bulanan $=4.98 \times 31 \mathrm{hr}=147,183 \mathrm{~mm} / \mathrm{bulan}$

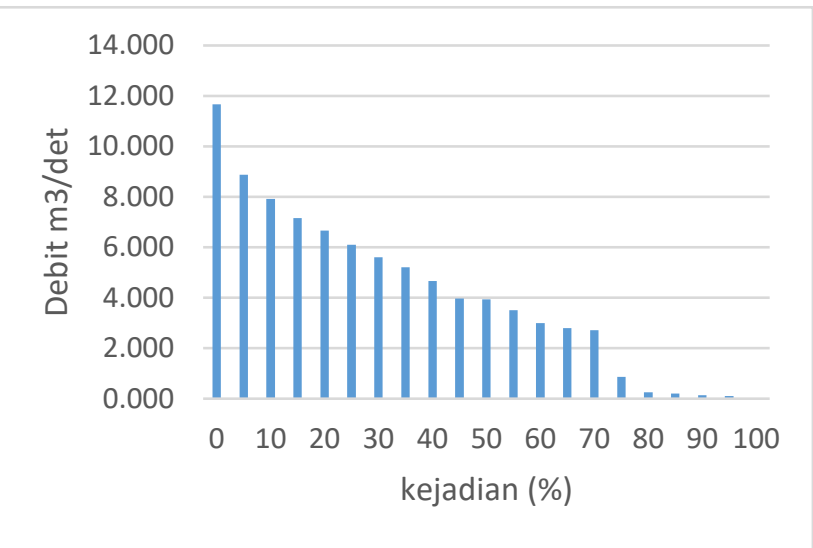

Gambar 4.2 Flow Curve Duration

\subsection{Pemilihan Jenis Turbin dan Simulasi}

Berdasarkan head yang telah diperoleh maka turbin yang sesuai untuk pembangkit ini adalah turbin Francis. Turbin Francis merupakan salah satu turbin reaksi yang memiliki blade (sudu putar) statis namun guide-vanenya dapat bergerak. Guide-vane (sudu pengatur aliran) ini sangat berguna pada kondisi dengan debit air yang tidak tetap. Maka dilakukan simulasi pada TURBNPRO dengan memilih menu Turbin Francis. Berikut data hasil simulasi :

Simulasi menggunakan TURBNPRO

A. Data Masukan untuk Simulasi

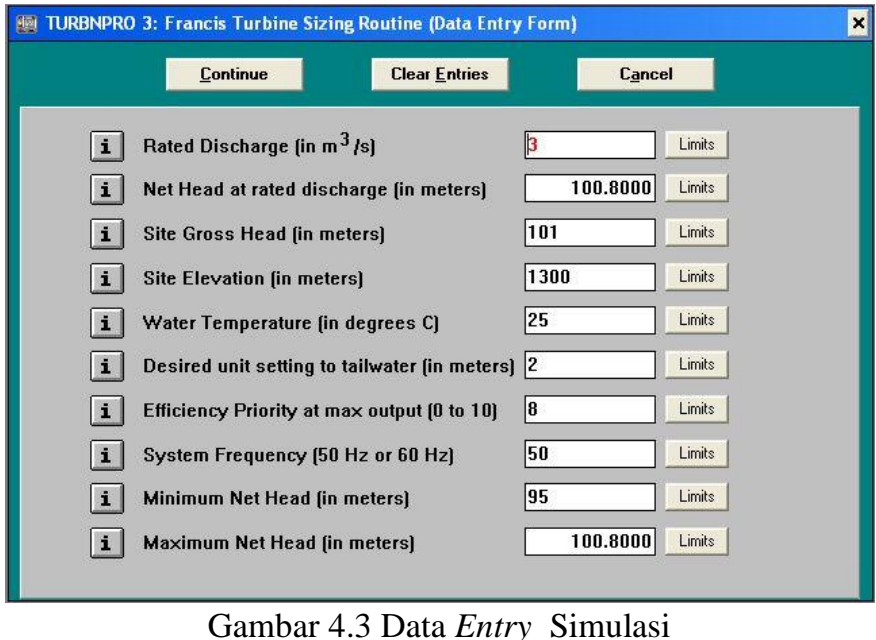

Gambar 4.3 diatas merupakan data entry simulasi dengan menggunakan turbin Francis. Data yang dimasukan merupakan data yang dimasukan berupa :

Tabel 4.1 Data Masukan Untuk Simulasi

\begin{tabular}{|c|c|c|}
\hline No & Parameter & Nilai \\
\hline 1 & Debit aliran & $3 \mathrm{~m} 3 / \mathrm{s}$ \\
\hline 2 & Head Efektif & $100,8 \mathrm{~m}$ \\
\hline 3 & $\begin{array}{l}\text { Head Gross atau hasil } \\
\text { pengukuran }\end{array}$ & $101 \mathrm{~m}$ \\
\hline 4 & Ketinggian Wilayah & 1300 \\
\hline 5 & Temperatur air & $25^{0} \mathrm{C}$ \\
\hline 6 & $\begin{array}{c}\text { Tinggi Saluran Pembuangan } \\
\text { dari Turbin }\end{array}$ & $2 \mathrm{~m}$ \\
\hline 7 & Efficiency Priority (0-10) & 8 \\
\hline 8 & Sistem Frekuensi & $50 \mathrm{~Hz}$ \\
\hline
\end{tabular}




\begin{tabular}{|c|c|c|}
\hline 9 & Head Minumum & $95 \mathrm{~m}$ \\
\hline 10 & Head Maksimum & 100,8 \\
\hline
\end{tabular}

Data debit $3 \mathrm{~m} 3 / \mathrm{s}$ dan data head efektif 100,8 m serta head gross $101 \mathrm{~m}$ pada data masukan diatas diperoleh dari perhitungan sebelumnya pada sub-bab ini. Data ketinggian wilayah 1300 mdpl dapat dilihat dari Google Earth. Data ketinggian wilayah ini bisa dipilih pada daerah sungainya, atau juga daerah sekitar tempat yang direncanakan untuk dibangun bak penenang. Data ketinggian ini akan berpengaruh juga pada performance dan dayaguna turbin nantinya. Data temperatur air bisa diperoleh dengan melakukan pengukuran langsung di lapangan. Data ini diperoleh dengan melakukan pengukuran minimal di 3 titik sungai kemudian di ratarata. Untuk lebih bagusnya, pengukuran tidak hanya dilakukan satu hari, akan tetapi dilakukan pencatatan rutin seperti misalnya data mingguan atau bulanan. Dari hasil pengukuran lapangan diperoleh nilai temperatur air sungai Cilaki adalah sekitar $25^{\circ} \mathrm{C}$.

Data selanjutnya yaitu desain tinggi dari turbin terhadap saluran pembuangan. Ketinggian ini bisa didesain sesuai dengan kondisi yang ada pada wilayah pembangkit. Pada data diatas dapat dilihat juga untuk Efficiency priority at max output dipilih nilai 8. Efficiency priority menentukan tempat terjadinya debit rata-rata pada daerah kerja turbin. Dengan memilih angka 8 maka debit rata-rata pada solusi turbin akan terjadi dekat dengan titik efisiensi maksimum head efektif rata-rata. Nilai frekuensi yang digunakan mengikuti nilai frekuensi PLN yaitu 50 Hz. Dan data yang terakhir yaitu data ketinggian maksimum dan minimum. Data maksimum diatur setinggi dengan head efektif sedangkan head minimum diatur sebesar $95 \mathrm{~m}$. Data maksimum minimum head ini merupakan input data untuk perhitungan performa turbin pada debit dan head yang berubah-ubah untuk memperoleh efisiensi terbaik dan daya listrik optimal yang dihasilkan.

\section{KESIMPULAN}

1. Perkebunan Malabar memiliki curah hujan tahunan yang tinggi yaitu 2300 - $3200 \mathrm{~mm}$ dan secara geografis daerah perkebuanan ini merupakan daerah berbukit yang dikeliling beberapa pegunungan diantaranya Gunung Tilu, Gunung Wayang, Gunung Windu, Gunung Kencana dan Gunung Kendang.

2. Debit desain ditentukan dengan analisis flow curve duration sebesar $3 \mathrm{~m} 3 / \mathrm{s}$.

3. Head yang di peroleh di lokasi pembangkit adalah sebesar 100,8 meter, dan dengan melalui perhitungan manual menggunakan persamaan 3.2 diperoleh besarnya daya listrik yang dapat dihasilkan adalah sebesar 2370,81 kW.

4. Dengan nilai head sebesar 100,8 meter jenis turbin yang cocok untuk pembangkit ini adalah turbin Francis, dan dengan bantuan software TURBNPRO telah disimulasikan menggunakan data yang ada maka didapatkan karakter turbin Francis sebagai berikut; ukuran diameter $771 \mathrm{~mm}$, kecepatan putar rata-rata $750 \mathrm{rpm}$, kecepatan spesifik turbin $122 \mathrm{NS}$.

5. Berdasarkan simulasi, karakteristik dayaguna turbin memiliki nilai efisiensi terbaik sebesar $92,4 \%$ pada debit 2,88 m3/s dengan head efektif sebesar 100,8 m, Pada head efektif sebesar 100,8 m turbin akan mengalami kavitasi bila nili debit yang mengalir pada turbin lebih dari $3,30 \mathrm{~m} 3 / \mathrm{s}$.

\section{DAFTAR PUSTAKA}

[1] KepMen ESDM Nomor 1122 K/30/MEM/2002, Pedoman Pengusahaan Pembangkit Tenaga Listrik Skala Kecil Tersebar, 2002.

[2] PerMen ESDM Nomor 26912/26/600.3/2008, Biaya Pokok Penyedian (BPP) Tenaga Listrik Tahun 2008 yang Disediakan Oleh Perusahaan Perseroan (Persero) PT. Perusahaan Listrik Negara, 2008.

[3] Dandekar M. M, Sharma K.N, 1991. Pembangkit Listrik Tenaga Air. Terjemahan, Penerbit Erlangga, Jakarta.

[4] Parabelem T.D. Rompas, Analisis Pembangkit Listrik Tenaga Mikrohidro (Pltmh) Pada Daerah Aliran Sungai Ongkak Mongondow Di Desa Muntoi Kabupaten Bolaang Mongondow, Jurnal Penelitian Saintek, Vol. 16, Nomor 2, Oktober 2015

[5] Sri Sukamta, Adhi Kusmantoro, Perencanaan Pembangkit Listrik Tenaga Mikro Hidro (PLTMH) Jantur Tabalas Kalimantan Timur, Jurnal Teknik Elektro Vol. 5 No. 2 Juli - Desember 2016

[6] KepMen ESDM Nomor 1122 K/30/MEM/2002, Pedoman Pengusahaan Pembangkit Tenaga Listrik Skala Kecil Tersebar, 2002.

[7] PerMen ESDM Nomor 26912/26/600.3/2008, Biaya Pokok Penyedian (BPP) Tenaga Listrik Tahun 2008 yang Disediakan Oleh Perusahaan Perseroan (Persero) PT. Perusahaan Listrik Negara, 2008.

[8] LIPI, Pembangkit Listrik Tenaga Mikro Hidro, 2005.

[9] Mrs. S. P. Adhau, Dr. R. M. Moharil, Mr. P. G. Adhau. Estimationnof Micro-Hydro Power Plant Capacity From Potential Sites. International Comperence on Power Electronics, Drives and Energy Systems. Bengaluru, India, 2012.

[10] Md. Rashidul Islam, Shaikat Barua, Regan Barua. Feasibility Study Micro-Hydro Power With an Integrated Renewable Model in CHT. Global Humanitarian Technology Conference. Bangladesh, 2012.

[11] Angela Lu Quilisch, KTH Electical Engineering. Object Oriented Modelling and Simulation of Kaplan Turbines. Stockholm, 2008.

[12] A.Harvey, A.Brown, P.Hettiararchi, A.Inversin. Micro Hydro Design Manual: A Guide to Small Scale 
WaterPower Schemes. Intermediate Tech. Publications London, 1993.

[13] Mukmin Widyanto Atmopawiro. PLTM Curug Malela Studi Kelayakan. Pusat Studi Mikrohidro ITB. Bandung: 2008.

[14] Direktorat Jendral Listrik dan Pemanfaatan Energi, Departemen Energi dan Sumber Daya Mineral, Buku 2A Pedoman Studi Kelayakan Hidrologi, 2009.

[15] Dandekar M. M, Sharma K.N, 1991. Pembangkit Listrik Tenaga Air. Terjemahan, Penerbit Erlangga, Jakarta.
[16] Suwignyo, Perencaan dan pembuatan Turbin Propeller untuk Pembangkit Listrik Tenaga Mikro Hidro (PLTMH), Seminar Nasional Sains dan Teknologi Terapan V, 2017.

[17] Danny Samuel Pelupessy, Pemilihan Type Turbin pada Pembangkit Listrik Tenaga Mikro Hidro (PLTMH), Jurnal Teknologi Volume 9, 2012

[18] Ade Rahmat, Simulasi perancangan Turbin Propeller sumbu Vertikal untuk pembangkit listrik Tenaga Mikrohidro, Univertitas andalas 2011 